\title{
CORONAVIRUS IN LIGHT OF PHILOSOPHY
}

\author{
Emil Vlajki \\ Faculty of Political Sciences, University of Banja Luka, Banja Luka, Bosnia and Herzegovina
}

\begin{abstract}
The history of humanity is a history of rationality. As a result, mankind has progressed from the Stone Age to the era of modern medicine, genetics, computer science, robotics, and nanotechnology. The life span of a man in ancient times was about twenty years, and today, in highly developed societies, a man lives, on average, to eighty-six years. Advances in science and technology have not always had a positive impact. Suffice to say, the ongoing environmental problems that seriously affect humanity or, for example, the dietary problems that have resulted due to genetic manipulation. Scientific and technological development must be considered in a serious and philosophical manner. Ethics are increasingly becoming an integral part of life. In this paper, we focused on the new coronavirus that has led to the planetary-wide disease called COVID-19. All countries have engaged in their efforts to suppress the resulting pandemic. However, some of the utilized measures have been suspect: whether to lock-down people in quarantine, whether their movement should be restricted, whether they should be forced to vaccinate, and so on. Claiming to act prophylactically, scientists, by adding some DNA, RNA segments (gain of function, GOF) to an innocuous human virus, have created a dangerous artificial influenza virus. Likewise, an artificial, infectious coronavirus was created in a laboratory. Both procedures for creating these dangerous, hybrid viruses have been described in eminent scientific journals. The scientists involved in this research told us that they wanted to find cures and vaccines for these non-natural viruses on the offchance they ever appeared among humans; when carefully handled, engineered organisms provide a unique opportunity to study biological systems in a controlled fashion. Biotechnology is a powerful tool to advance medical research and should not be abandoned because of irrational fears. But the chance of this type of virus appearing among humans is almost nonexistent. However, what if these viruses "escape" from the lab, as has happened in the recent past? What if a terrorist organization start producing these viruses on their own according to detailed instructions and then use them? Finally, since the two great world powers, the US and China, that jointly created the artificial coronavirus, called SHC014-MA15, who can stop them from continuing this practice? Isn't it possible that they also created the current SARSCoV-2 provoking a death of two and a half million people? Related to these questions, this study deals with the issue of tolerance. A large number of world-renowned scientists really believe that the current cause of the pandemic, SARS-CoV-2, is an artificial, laboratory-created virus, presenting a number of facts for this. It is not disputed that their claims are arguable. This, however, does not mean that their opponents, pharmaceutical companies and some superpowers, who have far greater political and economic power, have to incorrectly and utterly embarrass them all over, morally discredit them, nor ban their texts on the subject. In science, the struggle must be waged by arguments, not by totalitarian Orwellian methods. Keywords Hegel, philosophy of history, rationality, "cunning Mind", geopolitics, ethics, communication, genetics, coronavirus, scientific and technological development, future of humanity
\end{abstract}




\section{PART ONE}

Philosophy, and Everyday Life in the Age of Corona

Many prominent figures - scientists, journalists, and politicians - believe that humanity will never be the same, after the COVID-19 pandemic that has killed two and a half million people. At first glance, this thesis seems to be unfounded. Throughout history, there have been other pandemics with far greater casualty counts such as, the plague pandemic. Furthermore, the influenza pandemic of 1918 caused the deaths of tens of millions of people, but humanity continued to exist as normal. History has its own course and meaning, and to change it is impossible. Nevertheless, if the claims of many famous scientists are correct, the new, laboratorymade coronavirus will make a difference in history. It will continue to scare people with its mutations, and will be accompanied by other hybrid (laboratory, artificial, synthetic) viruses which are nonetheless deadly. The masses will be permanently preoccupied with their health, will be terrified, will lose interest in everything else, and will become subservient to their rulers. In this way, the inhuman flow of history will be strengthened.

\section{Introduction}

In order to understand the meaning of COVID-19 in everyday life, it is necessary to present the basics of the philosophy of history, especially Hegel's. It forms the foundation of a Western Judeo-Greek-Christian civilization whose main characteristic is rationality $/ \mathbf{1} /$. Judaism in biblical Genesis indicated the creation and evolution of life (such evolutionary flow is not at all different from that of Darwinism), and determined two basic, priority directions of movement of the West: scientific rationality and the effort to prolong life /2/. Greek thought is responsible for understanding dialectics (Heraclites) and formal logic (Aristotle). Christianity made it possible, by introducing Aristotle's formal logic into medieval universities (thanks to Toma Aquinas), which meant a consolidation of rationality as an imperative of Western thought and life in general. The Western world, thanks to rationality, proved to be so dominant that in the late nineteenth century, it controlled, in colonial form, nine-tenths of humanity. Of course, rationality is a possible feature of all societies, only many of them, for climatic, ideological, religious and other reasons, have not prioritized it and left it in the background $/ 3 /$.

Hegel marks the end of philosophizing about the foundations and movement of the world.

In his mind, and following the Greek philosophers who felt that the world was rational and divine, the ("cunning") Mind occupies one of the central places. The Mind, starting from sensory certainty, passes through phases of consciousness and self-awareness. Then, at the end of its journey, is realized in its mature form and becomes the basis on which all social relationships are built; according to Marx, this foundation is Western scientific rationality. History, then, is meaningful and takes place dialectically. Marx, who, in his own words, "put Hegel's philosophy on its feet," sees the dialectics of history as a succession of economic epochs. History first takes the form of a paradigm that is a set of fundamental patterns on which the functioning of a society is based (for example, slavery, feudalism, and capitalism), having its own real side - production forces and relationships - as well as appropriate ideological superstructure.

Over time, a paradigm becomes unattainable, full of contradictions, dysfunctional, resulting in the formation of a new paradigm. This manifests itself as a clash of forces, the supporters of the old paradigm against those who are advocates of a radically new, more advanced way of life, for example, the conflict of feudalism between the feudal lords and the representatives of civil society. Theoretically, this can be presented as a conflict between a thesis and its antithesis resulting in synthesis - a new, more advanced paradigm. Of course, this is only a theoretical scheme of the unfolding of history and in appearance it does not play out linearly; it has its aberrations (the Inquisition, Nazism, gulags), but, the bottom line is that a new, more advanced paradigm prevails.

The only question is whether in today's postmodern epoch, without history and any single big 
idea to drag humanity forward, do we live meaningfully? What kind of mind leads us? It looks more like Frankenstein's than a human's /4/. In science, we alienate our souls and our freedoms, which we will illustrate with a few examples, who are bound in the age of corona, as the philosopher Eugen Fink would say, to the basic phenomena of life.

\section{Communication, Friendship and Love in the Time of Corona}

1.

Name: Ethan Lane

Age: 22

Occupation: Data Analyst

Location: London, United Kingdom

I first met Patricia during my first year of university. We had a short fling two years back when she was on a break with the guy she was seeing at the time. But after our initial fling, she went back with her then boyfriend and we didn't speak for two years.

When lockdown was happening in the UK, my family took the last plane back to New Zealand. I stayed behind. I was furloughed at the time and was stuck in the house. A couple of days later Patricia sent me a message, and it turned out she had been living down the road from me. Initially I panicked, but she made me laugh in her messages, and I finally replied back.

At the time, we still didn't really know what the rules were. I think everyone was extremely lonely, isolating by themselves. And I guess for me, lockdown really helped my dating life. I was used to travelling and bouncing around, and quarantine settled me. I asked Patricia if she wanted to quarantine with me, and we've spent the entire lockdown together. We did all kinds of things, like move the chair out to the garden, cook together, work-out together at home and even I got a Disney plus subscription.

She's not officially my girlfriend yet, but I am going to ask her. I am actually going to buy 200 pieces of rods and stakes and stick them in the ground, and have it spell out 'Will You Be My Girlfriend?'. She won't be able to see it from the ground, but if you climb up to the roof, you will be able to read it.
I think if it wasn't for the lockdown, I would have found a million ways of not spending time with her. Quarantining together was kind of like, we're in this together.

2.

Name: Jakub Chmurka

Age: 22

Occupation: Entrepreneur

Location: Warsaw, Poland

I was living in Western Poland during the initial outbreak of Covid-19. I got on Tinder and found myself chatting to three girls. But honestly it really wasn't that interesting, and it really wasn't going anywhere. Around three to four months ago, I moved to Warsaw, and I went on Tinder again. And it was crazy! People were just getting out of lockdown, and we were in the phase where people were ready to go out but still cautious.

We were talking about how we were all doing during the pandemic; things like how it impacted them and what they were doing given the situation. People had been pretty trusting on Tinder. It was loosening up. There were a lot of girls on Tinder looking, it was quite clear. Typically, they're usually less assertive. I met up with a couple of people, but it wasn't super nice, and I really didn't meet them again.

But as the epidemic was slowing down, I was also talking to a friend from London, who had a female friend flying into Warsaw. The female friend was going to be quarantined for two weeks and wasn't able to leave her house. I wasn't in lockdown, but I wasn't meeting that many people. Warsaw was a new city to me, and I didn't have my community there and I wasn't meeting too many people during the aftermath of Covid-19. So, I agreed to go over to the girl's house along with my friend.

We went to hers' to have some wine, listened to music, and I thought she was the most intelligent woman I had ever met. She was so freespirited and also extremely cute. We told each other about our coronavirus stories and what we did during lockdown. I was making eyes with her, and there was definitely a connection. We've started going out ever since. It was definitely more organic than going on a dating app. 
3.

Name: Simon W

Age: 25

Occupation: Personal Trainer
Location: Singapore

During the coronavirus lockdown when I was in Singapore, I downloaded Tinder. I think most single people who are bored download Tinder. I considered it a bit of a pastime. I ended up matching with this girl on the app. She was beautiful and super funny. I like talking to people in general and it's always nice to chat with someone who is impartial to your life, someone who doesn't have a bias or an agenda. The conversations were good, and it was more relaxing than dating someone in person.

Obviously, it was a shame we couldn't see each other in person, and so I suggested we meet up at the supermarket. She jumped at the idea and I was also very keen. We both loved going to supermarkets, so we would go and pretend to shop. It was really nice. We felt like we had known each other a lot longer than we actually had. It was quite an experience walking around the supermarket doing groceries, exchanging compliments and I even asked about her parents. I wouldn't have changed much apart from not wearing a mask and maybe some physical contact!

There was no concern about catching the virus as we both have been isolating and social distancing. But after doing the supermarket shopping date twice, I figured how strict the government is with fines and honestly, I just really didn't want to be fined.

I eventually went back to the UK, and with the time difference and not being able to physically be there or have that intimacy, everything kind of fizzled out. When you start an online relationship and you don't go out with them, it's a very different dynamic, there's not much intimacy. So now, at this moment, I am still on a dating app $/ 5 /$.

\section{"Humane" Eugenics}

The Frankenstein vision in the corona era is stated in an everyday situation full of pain, illogicality and leaves me without answers to many questions.
I feel like I am on the other side of the mirror, where the world has different rules, the true ones that can only be known when there is some tragedy of the broadest proportions $/ 6 /$.

The first thing that amazed me when the pandemic began was death itself. Thousands of people died every day in places where they should never have died. They died of coronavirus in the most developed countries in the world where medical care is of the highest level. I follow the media and see statements from their politicians who claim they did not do well! Furthermore, even if they did not initially find their bearings, and no one got by at first glance, they have the best possible medicine and their mortality rate should have been significantly lower than that of less developed countries.

Moreover, while out, walking down an empty street, I recall, I came across an acquaintance everyone calls Humpty Dumpty because he is kind of round-shaped like an amorphous egg, and he hums more than he speaks. I see he is not wearing a mask like myself; he knows, then, that there is no virus in the air. I ask him about this illogicality related to mortality, and I tell him that in these countries of prosperity, humanism and respect for human rights, such a thing should not happen. He smiles pitifully, thinking that I, who everyone thinks is so mindful, don't understand anything.

"I know why you don't understand anything," he replies. "You're on the other side of the mirror, so it's all messed up for you. People are dying en masse from coronavirus, and those over eighty, precisely because these countries continue to strive to remain humane and develop human rights."

I am speechless after this dialectic of words.

"There are a lot of old people out there (he is looking at me intensely as if this reference applies to me too) who are living longer, are unproductive, almost parasitic, wasting their social security payments which could be better $\mathrm{u}$ sed by younger people, and are a detriment to the economy. They will die, of course, very quickly, so why do they need to linger when there is already an opportunity to be less harmful to society? /7/ 
I am off. I'm constructing a new poem where one row is read from right to left and the other, from the bottom up."

"What distorted poems is he talking about? There must be something wrong with him today. As for his conspiracy theory of the right wing (because what else could he be thinking of) against old people, this is not possible, because it would be genocide of the same proportions as that of Jews in World War II. Killing the old so that the younger ones can live better in more favorable economic conditions? That is crazy. I'm sure it's something else, maybe the leaders of those countries really don't know their way around."

The U.S. Coronavirus Response Might Be a Crime Against Humanity

The U.S. coronavirus response "is getting awfully close to genocide by default," Yale epidemiologist Gregg Gonsalves tweeted last May-several hundred thousand deaths ago. Gonsalves's use of the term genocide is dramatic. But the scale of the death toll in the United States is on a par with genocidal actions of the past. Stalin's man-made famine in Ukraine is believed to have killed 3.9 million Ukrainians over two years, 1932-33. The Irish famine resulted in 1 million deaths over seven years, from 1845 to 1852. Researchers at Columbia University compared the Trump administration response to COVID-19 to the response of other nations and estimated that the ineffective strategy in the United States resulted in 130,000 to 210,000 needless deaths over less than a year.

That study was released at the end of October, and since then U.S. numbers have only grown worse. There were about another 100,000 deaths in November and December combined, and as of today, the United States has lost just over 400,000 people. Some projections have the United States hitting 500,000 deaths by early February 2021. Currently it looks like most people will need to wait months to receive vaccine shots, which means tens of thousands more are likely to die at the minimum before the virus starts to recede.

The numbers are stark: The virus has killed more Americans than died in the Vietnam War or in World War I. ... There's unlikely to ever be an international trial of Trump officials for crimes against humanity or genocide. In that sense, the discussion is going to remain an academic one. But it's worth thinking about genocide and the president's response to emphasize that the administration is culpable for letting people die by the tens and hundreds of thousands.

The Trump administration has been culpable, at least in part, for a death toll on a genocidal scale. So, is Gonsalves right? Does it make sense to consider the Trump administration response to COVID-19 as a genocide?

The U.N. defines the crime of genocide as "acts committed with intent to destroy, in whole or in part, a national, ethnical, racial or religious group, as such." Acts which can be considered genocidal include "killing members of the group," "causing serious bodily or mental harm to members of the group," or creating conditions designed to destroy the group.

For the U.N. and international prosecution of genocide, intent is important-there has to be evidence that a government set out deliberately to destroy a national, ethnic, racial or religious group. At first, at least, that might not seem to be the case in the United States, where the death toll has scythed through the whole country.

And yet, there is some evidence to suggest that the Trump administration did in fact intend to use COVID-19 to target certain political and racial groups. According to reporting from Vanity Fair, Trump's son-in-law and advisor Jared Kushner shelved a federal COVID-19 testing plan because he believed that the virus would mostly affect Democratic states, and the administration could then blame Democratic governors for deaths. Blue Democratic cities are disproportionately home to Black people and other minority populations. A federal plan to allow deaths in blue states inevitably and predictably disproportionately facilitated the deaths of Black people and other people of color.

These decisions, coupled with entrenched racist inequities in healthcare, led unsurprisingly to disproportionate outcomes. As of Jan. 5, Black death rates and Hispanic death rates from COVID-19 were 2.3-2.5 times those of white 
people, according to the CDC. Indigenous death rates were 2.2 times those of white people $/ 8 /$.

\section{Covid-19 Is Killing Black People Unequally-Don't} Be Surprised

The Centers for Disease Control and Prevention has found that several racial minority groups account for a disproportionate number of the Covid-19 cases and fatalities in the United States, but the black community in particular is suffering. In Wisconsin, a state that is only 6 percent black, black people account for about half of its Covid-19 deaths. In Chicago, black people account for 70 percent of deaths due to Covid-19 but make up only 30 percent of its population. In Richmond, Virginia, all but one of the people who have died of Covid-19 were black. "I'll tell you the first thing I said when I saw the disparities in fatality rates," says Louis Penner, a professor emeritus at Wayne State University who studies racial disparities in health care. "I said, 'People are surprised?'"

Anybody who is paying attention knows that the gulf between the health statistics of white and black Americans has existed for decades, or, really, centuries. Covid-19 is just the latest manifestation of an old and ugly trend. The explanation for it is at once simple-racismand incredibly complex. Structural inequalities have kept black Americans significantly poorer than their white counterparts, and economic disparity creates health disparities, especially during a pandemic. Black people (and other minority populations) tend to live in more polluted, more densely populated areas, have more people per household, and are overrepresented in settings where people are unable to effectively social distance, like prisons and homeless shelters. They disproportionately work jobs currently considered essential, yet also are far less likely to have paid sick leave, enough savings to take time off, or a grocery store nearby enough to stock up easily.

Many of these factors, from living in food deserts to lacking health insurance, add up to mean that black communities also suffer at higher rates from acute and chronic medical conditions $/ \mathbf{9} /$.

\section{They Are Trying To Kill Us}

When the test came back positive, Quinn felt like he was getting a second sentence. "I believe that they sent COVID here to kill us. Simple as that," he says. He's a father living at San Quentin State Prison and one of over 2,200 inmates who've tested positive for COVID-19. The correctional facility, located in Northern California, is the center of the largest coronavirus outbreak in the country.

San Quentin was likely a preventable tragedy. Since March, experts have been warning that prison outbreaks of COVID-19 would be deadly and calling on federal judges to release inmates and reduce the size of the prison population.

That happened too late in California. Instead, the California Department of Corrections and Rehabilitation (CDCR) moved men away from a prison in Chino, which was battling an outbreak, to San Quentin, which was virus-free. In doing so, they created a second hotspot - one even more deadly than the first. By July, more than a third of people at San Quentin had the virus, according to a report in Nature. By August, 24 inmates were dead.

America's failure to stop the virus from spreading in prisons is a key piece of its failure to contain the virus at large. Tens of thousands of people in prison have tested positive for the virus. From March through the beginning of June, the number of COVID-19 cases in US prisons grew at a rate of around 8 percent per day, compared to 3 percent in the general population. Of the top 20 largest disease clusters in the country, 19 are in prisons or jails.

To the men at San Quentin, this doesn't feel like an accident. Speaking to The Verge on contraband cellphones, inmates discussed the systemic failings that led the facility to become a viral epicenter - failings they interpreted as intentional acts of aggression. While the men are largely cut off from the outside world, information trickles in, and conspiracy theories abound.

One theory, which Quinn believes, is that prison authorities released COVID-19 on purpose to kill off the prison population. "The governor said they weren't going to execute people on death row anymore. So they sent the virus here 
to do what? To kill off people on death row," he says. "They cost more money than anyone else here. So people like me are getting swept up in the process."

His concerns may sound merely like rumors, but they reflect a deep-seated mistrust in the institution. That mistrust is, in many ways, warranted: while CDCR might not have intentionally released COVID-19 into the prison, months of political jockeying and legal fighting slowed the prison's response to the pandemic and directly contributed to the outbreak. Instead of taking steps that could have kept inmates healthier, the system went down a path that made it easier for them to get sick /10/.

\section{Existentialism}

People are already publishing stories about the suffering that breaks them. I have softened considerably. There is nowhere to go; nothing works except what is most necessary for existence. Even if I meet someone on the street, we just say goodbye. I miss the handshake, and only now do I realize how important it was. I also miss meaningless gatherings where nothing clever is said. I live alone, I play chess with a computer, and sometimes I play something on a synthesizer, extremely amateurish. However, none of this can make up for hanging out with people. That is why I read a lot and cry a lot.

I have learned something. It is true that old people die en masse in this age of corona, but not everyone dies from it. With coronavirus, some of them would somehow survive, and cope; however, they still die of loneliness /11/. I am reading for the second time this tragic letter from a medical student who has been volunteering at a hospital, exhibiting that form of existence, without human essence, must result in death.

"I experienced extremely stressful times for many healthcare professionals. Everything is a mess. I have not seen the head doctor in days, if not weeks. It seems to me that everyone faces an extraordinary situation, and yet I miss the small, constructive gestures on their part that would give me more courage and hope. We have had extra shifts for three weeks and we are staying overtime. Most often, we spend the night here. Moreover, at Easter, there were no hospital administration. That's sad, even though I know they have conflicted concerns right now.

Recently, there is a new official name for my workplace: 'Corona -- The Intensive Care Unit for Patients'. When the new corona virus arrived at the hospital, the initial approach was a 'wild improvisation', which alarmed staff. As I wrote to you, we started work a few weeks ago on a ward that was not envisioned at all as a ward for coronavirus patients. The lockers were empty; the walls were old and dilapidated. The floor had holes, some windows could not even open, through others there was a constant flow of air. Everyday life was oppressive.

However, the staff at this department are doing their best and testifying to the shocking stories that coronavirus imparts. You just cannot help people. There is no effective therapy. People are alone with their illness and it weighs us down. Now we are just carers or administrators of painkillers. People die every day, and so do we in our hearts with them. Two doctors got sick and one nurse. Luckily, their symptoms are not severe. As far as I am concerned, I feel fine.

After seven weeks of working in this workplace, no one has ever entered this department except the staff. As in many other hospitals, there is a ban on visits since the relatives even when they are initially escorting the patients, have to wear masks just like us. That is, take hairnets, FFP2 or FFP3 masks, and put hoods on your head, put on a protective suit, two pairs of gloves... In reality, it is just not doable.

In addition to that, many older people, often those who have made it from nursing homes to hospital, are terribly lonely. They actually give up faster. There are patients who came to us in relatively good condition, quite healthy, and then somehow gave in to the virus. Two or three died, I'd say, of loneliness."

\section{Religious and National Madness}

In the corona era, can one think of something "more important" than being to help one's fellow man, to understand him with much empathy, to strive not to hurt him?

Looks like it is not going to happen. Moreover, in times of death, people remain slaves to their prejudices, and their level of intolerance towards 'The Other', "intrinsically" and "hostile" to different ones, does not diminish. Even when that "enemy" is dead! 
"Digging the grave was slow and torturous. Dr. Pradip Kumar and his two assistants were digging for grave by handing out one shovel. While one shoveled, the other two would dig for grave with their hands, desperately and hurriedly catching mud, looking back every few minutes.

About two meters deep, they stopped. Kumar, overwhelmed with grief, wrapped the body of his colleague, Dr. Simon Hercules, in his grave, and then quickly covered it with dirt. Under cover of night darkness, three men ran from the cemetery regardless.

Dr Hercules is one of several doctors who have died because of COVID-19 in the Indian state of Tamil $\mathrm{Nadu}$ in the past few weeks. India is teeming with misinformation about the pandemic, and one of them is the country-wide belief that the virus can be spread from a dead man to a living person.

Hercules was known at Chennai's New Hope Hospital. This 55-year-old, neurosurgeon and general manager of the hospital was known as a conscientious man. Nothing could stop him from helping the patient, not even the pandemic.

However, three weeks ago, he started coughing and got a fever, and then he was put on a ventilator. Because he was already vulnerable being a diabetic with high blood pressure, he passed away. Although news of his death from COVID-19 was broadcast on local TV stations, the public reaction was not sadness, but anger. As Hercules was a Christian, his body was to have been buried, not cremated, as is the custom in Hinduism. That night, about 200 people gathered at a Christian cemetery to demand that the plan for the doctor's burial be suspended, fearing that the virus would be transmitted from the deceased to the ground and thus somehow continue to spread the epidemic further.

An emergency solution was adopted to bury the doctor in another cemetery. However, as his wife Anandi, their 18-year-old son Anton, and colleagues, including Dr Kumar, stood by the grave, an angry mob came to the cemetery.

The mob demanded that the mourners leave immediately and take the body with them before it transmitted the virus to everyone. They attacked the bereaved with sticks and stones. They all had to flee in order to save their lives. Even the ambulance drivers were badly hurt themselves as they desperately returned the body to a vehicle when all of the windows were smashed.
After he returned to the hospital, Kumar called two assistants, put on protective gear and returned to the damaged ambulance. The bag containing his body was covered in glass and broken medical equipment. They drove back to the cemetery at midnight and dug a quick grave, all the while fearing the mob would return."/12/

\section{Death and Enrichment}

I spent the first year of the most recent war in Sarajevo, Bosnia and Herzegovina. There I watched humanitarian aid disappear from the magazine, and it re-appeared on the black market. A post-war generation of millionaires was being created based on suffering and death. Something similar is happening today.

In addition to the destruction of hundreds of thousands of people, the economy of many countries has been destroyed. Thus, for the first quarter of this year, 2020, a 5.4\% drop in working hours worldwide was calculated, which is 155 million jobs less than the fourth quarter of last year. Their 'saviors' will once again be the same ones who rule the world economy, which is otherwise called neocolonialism. Finally, the corona-feared population 'to the bone' lost, fearing disease, every critical consciousness and allowed authoritarianism, in various forms, to take over their lives.

The most ordained of all is the fact that this tragic situation has benefited the richest.

So, for example, according to the media, the wealth of American billionaires increased by more than $10 \%$ in just three weeks of the corona crisis.

Namely, of the 400 richest people on Forbs' list, at least eight billionaires have earned, since the pandemic began, $\$ 1$ billion each. Only a few of them with higher earnings are the founders of Zoom, owners of Microsoft, Skype, and Microsoft Teams. Yet none of them profited as much as the founder of Amazon - Jeff Bezos made $\$ 25$ billion as of January 1, 2020./13/

On the other hand:

GENEVA, 01. 10. 2020. "The International Labor Organization (ILO) warned today that the coronavirus has led to a massive drop in workers' incomes worldwide and to a growing inequality between richer countries that have 
provided money for their economies and poorer countries that have been unable to do so. In its report on the effects of the pandemic on the working world, the UN agency estimated that workers' global income in the first nine months of this year was lower by $\$ 3.5$ billion, down almost $11 \%$ from last year.

COVID-19 will plunge between 88 and 115 million people into extreme poverty, which could rise to as many as 150 million people in 2021."

"Extreme poverty, defined as living on less than $\$ 1.9$ (1.6 euros) per day, is projected to rise for the first time this year since 1998, when the Asian financial crisis shocked the global economy, according to the BBC.

Before the coronavirus spread around the world, the rate of extreme poverty was expected to fall to $7.9 \%$ this year, but in the end, the pandemic is likely to contribute to between $9.1 \%$ and $9.4 \%$ of the world's population living in extreme deprivation."/14/

\section{Death is not Evenly Distributed}

(Racism and Social Inequality in Dying from COVID-19)

U.S. President Donald Trump, age 74, was transferred Friday October 2, 2020 to Walter Red Military Hospital near Washington, D.C., not a full day after he was confirmed to be infected with coronavirus. On Monday 5 October, after only four days of treatment, he was out of the hospital COMPLETELY HEALTHY. Meanwhile, millions of infected people of his age group, those who belong to the risk group and who are being mercilessly destroyed by corona. They are tormented during recovery which lasts a month or more, and many of them do not survive.

Trump was treated with a cocktail of antibodies derived from the blood of cured patients called REFN-CoV-2 (manufactured by pharmaceutical company Regeneron). It is administered intravenously, reduces the amount of viruses and blocks their spread.

It is argued that this drug is still in the study phase, therefore unsafe, but who would dare treat the President of the United States with something untested, unsafe, and the like. On top of that, the president of the company that makes the drug, Leonard Shlifer, is Trump's friend. Upon leaving the hospital, Trump declared that he would do anything to make this drug available to all Americans! Of course, since then no one has even been talking about the drug and treatment with 'REFN-COV-2'. Maybe the doctors at that hospital lied and treated Tramp with something else they would not report about to the public. HOWEVER, IT DOES NOT MATTER AT ALL. IT IS IMPORTANT THAT AN OLD PERSON WHO IS INFECTED WITH THE NEW CORONAVIRUS HAS A GOOD CHANCE OF GETTING BETTER IN FOUR DAYS! Everything else is hiding truth and demagogues. Why don't these highly developed democratic societies, their governments and gigantic pharmaceutical companies do not announce to everyone a new means of treatment using drug that has proven to be effective in the case of the President of the United States? Of course, they will never do that. Firstly, in laboratories, they produced a virus, SARS-CoV-2, the first of its kind since life existed on earth. This virus is seriously harmful, especially deadly amongst the elderly (population of the third age), and to a lesser extent for younger people who have severe chronic diseases. Then they found an effective treatment method for all!

In the United States, where more than 500,000 people have died since the advent of the new coronavirus, racial and social discrimination is still very much present. Three "colored" people (Hispanics, African-Americans, indigenous people) die for every white man. The social front is an even worse situation.

\section{The Funny Aspects of the Corona Tests /15/}

The President of Tanzania, Djon Magufuli, in a satirical way, who entered the annals of black humor, described the dubious and manipulative value of the tests of the time.

"We took a sample of papaya, we took a sample of car oil, we took samples from various other things, and we took them to the lab. Nobody knew about it. We gave the samples the names of people. We named the sample from the car oil Jabil Hamza, a 30-year-old man, and the result came back negative. We took a sample from the Jackfruit fruit; we named it Sara Samuel, a 45-year-old woman. 
The result came back undetermined. Then we took a sample from the papaya, and named it Elizabeth Anne, a 26-year-old woman. The result of the papaya came back positive, that is, that this imaginary person has corona. We took a sample from the partridge, it came back positive. We took a sample from the rabbit, the result was indeterminate. We took a sample from the goat, it came back positive. We took a sample from the sheep, it came back negative. And so on, and so on.

Therefore, when we take a sample from a man and the result is positive that he has corona, it means that the fruit of the papaya should be in isolation, and the goat should be in isolation. It's obvious that dirty games are being played with these tests and that amazing things are happening in this country."

\section{White Man's Burden}

The anger of the West over China's economic success has had a cultural impact. From ideological anti-communist funds, writers, filmmakers and historians were stimulated to place future infections and pandemics,

through their books and films, in China, which should be accused of being a hotbed of evil in the world.In the planned, long-term anti-Chinese campaign, special attention was drawn to the cartoon series "The Simpsons", which first "predicted" the outbreak of a virus in a "yellow race" country in the 1993 episode "Marge in Chains!" In the film "Contagion" with Oscar winners Matt Damon and Gwyneth Paltrow, the American returns to Minnesota from Hong Kong, and dies a few days later, and her husband, and the rest of the planet, are struggling with an infection that is spreading like wildfire.

The new virus, which originates from China and causes severe respiratory problems, is treated with chloroquine, stopped by quarantine, and everyone wears masks. This is the scenario of the 14th episode of the second season of the American series "Dead Zone 2" from 2003. The example of an unknown writer and cartoonist who made a comic for the EU in 2012 is also relevant, where China is also accused of producing and spreading the current coronavirus in its laboratories. Back in 2012, the EU commissioned and published the comic "Infected", which largely predicted a global pandemic. Yet globalist visionaries are ultimately saving the planet. "Infected" was a production of the International Cooperation and Development Group of the European Commission. It was not intended for broad public dissemination, but was distributed within the EU institutions. The novel featured scientists in a laboratory in China experimenting with deadly pathogens. Suddenly, a "hero" in the form of Jesus appears from the future, representing an antidote from space. Then the evil opportunists stole the medicine from the hero and sold it to a pharmaceutical company. The aforementioned story from 2012 also contains the transmission of a new virus from animals to people in crowded markets like the one in Wuhan!

On top of these attacks on China was the lie that spread around the world in 2020. Japanese pathologist Tasuku Honjo, who won the Nobel Prize in Medicine in 2018 for his achievements in cancer treatment, who reportedly said the following: "The virus is completely artificial. I worked at the Wuhan Laboratory in China for four years. I am fully acquainted with all the laboratory staff. I called them all after the coronavirus appeared. But all their phones have been dead for the last three months. It is now understood that all of these laboratory technicians have died. I can say with $100 \%$ confidence - the coronavirus is not natural. It did not originate from bats. China produced it. If what I say today is false now or even after my death, the government may withdraw my Nobel Prize. China is lying and the truth will one day be revealed to everyone." Tasuku Honjo immediately and decisively denied this misinformation. All of this is followed by the attacks of the Trump administration, which directly accuse China of deliberately releasing the coronavirus (SARS-CoV-2) into the world.

Since the mid-twentieth century, various viruses have broken out including influenza (avian and swine), Anthrax, Ebola, HIV, Zika (African, Asian), SARS, MERS, and SARS-CoV-2. China did not have laboratories at all when most of these viruses appeared. The West found the ca- 
uses of these viruses in orangutans, chimpanzees, camels, birds, pigs, and bats - all in the non-western continents, "yellow" Asia and "black" Africa. The West is presented as white, virginal, constantly attacked from the outside. None of these viruses allegedly originated in the West, nor, of course, in its laboratories. At least strange, and racist, "conspiracy theorists".

\section{'Superfluous People' and Human Freedoms}

In the West, the absolute rationality is that, today, the foundation of every morality is in relation to the traditional notion of morality, reckless in its self-of-making; morality is what the ruling ideology imposes based on market-profit conception, and on the basis of scientific truth contained in computer programs. It primarily leads to the further, unfettered development of science and technology.

However, at the same time, such progress produces a large, permanent and irreversible job loss that creates a growing army of 'redundant people'. Intrinsically, the functioning of Western societies does not require more than ten percent of their inhabitants to run an entire society. Jobs can be found in informatics and management, but are becoming scarcer. Others find employment in the service sector where nothing is produced, thus buying social peace. 'Redundant' employment, is also found by people in the military sector, especially on military bases around the world. There they are reduced to expendable, live goods that, if necessary, participate and die in numerous "peacekeeping missions" that force less rational societies to formally accept Western standards of rationality, when in fact they serve to exploit raw materials and cheap labor so that the West can better fulfill its historical mission. Nevertheless, the service and military sectors have their limits in hiring people. The COVID-19 pandemic has caused a new wave of unemployment and hopelessness. In Western societies, tackling unemployment also takes place through strengthening of police forces that compel irrational individuals and groups to comply with the laws of stated behavior. Of course, in less rational societies, there may be a strengthening of the police, but the involvement of repressive forces there is historically barren, because it is far from any rationality in the Western notion of the word.

In this age of strong development of science, many are superfluous because, objectively, they cannot fit into this profit-oriented development because they have preferences that are beyond market logic.

Finally, the advancement of medicine and welfare is creating an increasingly burgeoning retirement class that is said to be becoming an emerging threat to the economy.

Theoretically, the question of 'superfluous people' does not exist in the abstract moral scheme of the West. Legally, all people are equal, but the poor segment of the population has only the right and freedom of painful survival. Thus, in the United States there are $12 \%$ of people (roughly forty million) living below the poverty line $\mathbf{1 6 /}$. They often have no abode or employment, no future, no health insurance, and their mortality rate is well above average. The fact is that "the majority of deaths due to COVID-19 were associated with poorer and more urban counties... These people may also have less access to testing and treatment resources. Policy makers who are struggling to deal with the effects of the pandemic across the nation at large may not have the resources to focus on this particularly vulnerable portion of the population." /17/

Internationally, in the "less rational, superfluous societies" that exist on the fringes of history, as the West qualifies them, the West continually intervenes, in various ways: "military missions of peace", by subjugation of elites, embargoes, creation of debt bondage, and so on.

With manipulation and weapons, people can be forced to remain silent and submissive, but this provokes hostility and revolt by the oppressed, and conflicts are eventually renewed. The West, finally, managed to achieve this and presented itself as their savior - with the help of science, the unconditional obedience of peoples around the world, and medical professionals and pharmaceutical companies. Therefore, we come to the new coronavirus (SARS-CoV-2).

Theories About COVID-19 
In 2020, different theories spread around the world, at a faster rate than the actual coronavirus.

- The coronavirus is artificially manufactured in U.S. and Chinese laboratories, as part of a biological war against China and the United States. Bill Gates created it personally, so that the vaccine would install a chip in our body and gather all the information about humanity that people have otherwise voluntarily left on their profiles. All this takes place under the watchful eye of the shadow rulers who control 5G technology, and the radiation of this telecommunications network alters the DNA with viruses and makes them deadly, which is only part of a secret plan to depopulate the population of our planet.

- Chinese Ministry of Foreign Affairs Information Department deputy director Zhao Lijian suggested that the coronavirus was delivered to Wuhan by the U.S. military. Republican Tom Cotton fought back, as he contended the virus originated in a lab in $\mathrm{Wu}$ han.

- On Russia's Channel 1, the virus has been linked to Donald Trump, and US security agencies and pharmaceutical companies have been accused of its emergence.

- Donald Trump claimed that the World Health Organization's data on the number of coronavirus deaths is false, and that Democrats inflated the possible consequences of the epidemic because they want to bring him down.

- In the most listened to radio broadcaster in the US, Talkies Magazine, host Rash Limbaug assured 15.5 million listeners that COVID-19 was a 'laboratory experiment by ChiCom', an abbreviation for Chinese communists, causing the Chinese to promote hysteria to take down Trump.

- In the UK, however, they were the most radical, they went from conspiracy theories to practice there, so in several cities they burned mobile phone poles and abused engineers, all because of the summed-up story of the $5 \mathrm{G}$ network as the cause of the pandemic.

- The BBC quoted a 'Washington Times' article about the virus being part of a Chinese biological weapons program performed by the Wuhan Institute of Viruses.

- Iran's 'Press TV' claimed that the coronavirus strain was developed by Zionist elements in the war against Iran. Iranian researcher Ali Akbar Raefipour was convinced that the coronavirus was part of the US 'hybrid war' against China and Iran, and Golam Reza Jalali, the head of civil protection, said it was an American biological attack on the two countries. In a letter to the UN, former Iranian President Mahmud Ahmadinedjad explained that COVID-19 is 'a new weapon to establish and/or maintain the political and economic advantage of the US in the global arena'.

- Various Arab-media outlets have also accused Israel and the United States of creating and spreading COVID-19, bird flu and SARS. British Conservative parliamentarian Tobias Evud publicly urged the Chinese military's Institute of Biological Products for 'greater transparency regarding the origin of the coronavirus'.

- The Russian Defense Ministry's Zvezda newspaper published an article entitled 'Coronavirus: America's biological war against Russia and China', claiming the virus is intended to weaken the Chinese economy. Russian politician Vladimir Žirinovski claimed the virus was an experiment by the Pentagon and pharmaceutical companies.

- According to one theory, Chinese scientists employed by a Canadian virus research lab stole coronavirus samples and sent it to Wuhan. The Chinese military portal Silu published a text with detailed 'information' that America had created a virus with specific traits aimed primarily at targeting the Chinese.

- One Chinese dissident, Dr. Li-Meng Jan, had a completely different story about the cause of the pandemic by claiming that China deliberately created the virus in military laboratories and spread it around the world. So the Communists would not kill her, she fled China for the United States, and told her story there, and all the Western media wrote about it.

-The BuzzFeed News portal has invented a conspiracy theory about the connection between the WIV logo and Umbrella Corporation, the fictional pharmaceutical company that created the virus to turn 'Racoon City' residents from the popular video game series 'Resident Evil' into zombies. 
- Coronavirus has thus been a weapon, a consequence of the greed of pharmaceutical companies, population control and the subject of spying operations. WHO Director General Tedros Adanom Gebrejesus said on this occasion: "We are not only fighting viruses in WHO, but also against trolls and conspiracy theorists who undermine our response."

\section{PART 2}

The New Coronavirus as a Metaphor for the Dictatorship of the "Cunning Mind"

Marx says that something that is conceived cannot be accomplished before social and technical conditions are created. Thus, until recently, rational Western societies used a number of repressive, utterly unpopular measures to effectively dominate "less rational societies" and thus enable historical progress. /18/

With the development of molecular biology of genes, especially genetic engineering, the 'cunning Mind' has found a way to begin to transform from a rough repression approach to something that will be as equally effective, with the West being completely exonerated. Simply put, it has begun, according to eminent world scientists, to laboratory-produce deadly yet artificial (hybrid, synthetic) viruses that he declared natural! In particular, they are the United States that, at least as far as one of these viruses is concerned, have been doing so in close cooperation with China.

\section{Evolution Will No Longer Be}

When a new coronavirus (SARS-CoV-2) appeared at the end of December 2019, causing COVID-19 disease and an international pandemic, the world scientific community was surprised, claiming it had never encountered anything like it before. This, however, was not true.

Coronaviruses have been known about for more than half a century. Without DNA genetic material with single-chain RNA, it has been shown that viruses from the family 'Coronaviridae' are parasitic, inanimate formations without metabolism. The diameter of these particles was measured to be 120-160 nanometers. They were named because of their appearance, which was beautifully seen by the electron microscope, which, due to their spikes on the ball body, resembled a crown. It has been established that this virus, a parasite, enters the human cell precisely with the help of these protein spikes, by connecting its sheath and the cell membrane, where in this way it would come to life by destroying its 'host'.

It was also discovered that ordinary human coronaviruses (four alpha coronaviruses), mainly, cause mild colds and infections of the upper-respiratory system, resembling an ordinary cold. Thus, it should be emphasized that a number of people who develop cold symptoms (most often-in winter) are infected with the viruses $\mathrm{HCoV}-229 \mathrm{E}$ and $\mathrm{HCoV}-\mathrm{OC} 43$, which are very widespread and common everywhere in the world. They appear sporadically, seasonally. In addition to the mentioned types of coronavirus, people can also become infected with types HCoV-NL63 and HCoV-HKU1.

Suddenly, there is a 'Copernican turn' with coronavirus! Mild alpha viruses, supposedly skipped hundreds (possibly thousands) of years of evolution and turned into murdered foreign bodies! Gene analysis shows that, in addition to the external form, the new coronaviruses have little to do with alpha viruses, so they are called beta coronavirus.

The first of these, SARS CoV 1, appeared in 2002. It spreads through droplets, via direct contact between two people, primarily attacks the lungs and in a couple of days, an infected patient is in serious condition. $10 \%$ of infected patients die. Fortunately, the disease is immediately detectable, so people can be urgently admitted to hospital. Doctors quickly understood how most of the infections were happening. Once patients were isolated, infections completely stopped within a year. Around 9,000 cases were registered worldwide. Finally, SARS CoV 1 disappeared completely, and no one knows what caused it! So, no vaccine was made. Most importantly, the disease is thought to have passed from one species of bat to humans, although it is not known how it happened. It took a miracle for this to happen directly! 
MERS appeared in Saudi Arabia in 2012. MERS (Middle East Respiratory Syndrome also known as camel flu) is a viral respiratory infection caused by MERS-coronavirus (MERS$\mathrm{CoV})$. Symptoms can range from mild to severe. Typical symptoms include fever, cough, diarrhea and shortness of breath. The disease is $\mathrm{u}-$ sually more severe in people with other health problems. There is no specific vaccine or treatment for the disease. The World Health Organization (WHO) recommends that those who are exposed to camels wash their hands and do not touch sick camels. They also recommend that camel-based food products be properly cooked. Treatments that help with symptoms and support the work of the body can be used. In the period from the onset of the disease in 2012 to the end of 2019, 2,499 patients were recorded worldwide; of which 861 died - the mortality rate is $34.5 \%$. By far the highest number of patients (about 80\%) were registered in Saudi Arabia.

A bat has been found to be infected with a virus that has exactly the same genetic structure as the infected camel virus, but no one knows how the infection could have occurred since bats and camels have lived in these areas since time immemorial and nothing like this has ever happened!

Finally, after an interval of eight years, the famous, deadly beta coronavirus, SARS-CoV-2, appeared, which is $80 \%$ genetically identical to SARS-CoV-1.

It is claimed that in December 2019 in Wuhan, the capital of China's Hubei Province, virus transmission occurred from an unknown reservoir to a human, after which the onwards classical spread from person to person continued.

At first, it was unclear whether the virus could be transmitted from one person to another, or whether all affected people became infected from a common, identical source. When they started to evaluate the medical care of infected people, person-to-person transmission quickly became evident. From China, the disease has spread to a number of countries.

Symptoms reported in people with 'Wuhan fever' included increased body temperature, exhaustion, dry cough, shortness of breath, respiratory distress, pneumonia, kidney failure, and in the most severe cases a fatal outcome. The onset of symptoms occurs between 2 to 14 days after infection, and it should be emphasized that infected individuals during this whole period are contagious and can transmit the infection (which was not the case with the first SARS coronavirus of 2002). The infection is spread primarily by droplets.

In most hospitalized patients, vital signs were stable in hospital, and laboratory findings showed a decrease in white blood cells (specifically leukopenia and lymphopenia). However, as many as a quarter of hospitalized patients developed severe symptoms of infection, mainly people with predisposing factors such as increased blood pressure (hypertension) or other cardiovascular disease and diabetes.

The first confirmed death caused by the new coronavirus was recorded on 9 January 2020 in China, and the mortality rate in people infected with SARS-CoV-2 and COVID-19 disease is 2.7 percent. What is characteristic of the three deadly coronaviruses, which appear every eight years, is the fact that in no case could be found a way to pass the virus from bat to an intermediary host (spillover), from bats /19/ to camels /20/ (MERS), and from bats to civets /21/ and pangolins /22/(SARS 1,2).

But the real story that comes from the 'cunning (Western) Mind', is just beginning and includes the fourth artificial, deadly beta coronavirus!

In the midst of the "Cold War" between China and the United States, the world sensation was the news that the two countries had jointly made an artificial beta coronavirus that was extremely dangerous to human health.

This is not another fake news story say Valère Lounnas, a Ph.D in molecular biology, and a doctor Gérard Guillaume in their articles on the COVID-19 in France Soir. This is an undeniable reality described in an open access article published in 2015 in 'Nature Medicine'. A completely unusual scientific text describing the production of a viable and highly pathogenic synthetic coronavirus for humans under the pretext of studying a potential pandemic. 
Lounnas describes the whole process $/ 23 / . \mathrm{He}$ says that the scientists responsible for these studies are Ralph S. Baric, professor and director of the Microbiology Laboratory at the University of Chapel Hill (North Carolina) and Shi Zheng $\mathrm{Li}$, a microbiology doctor who graduated from the Faculty of Science in Montpellier, now head of the laboratory of the Wuhan Institute of Virology.

In retrospect, this article refers to a situation in which in 2020 the entire planet was affected. After an introduction mentioning the global chaos that would result from a pandemic caused by bat coronavirus that would cross the species' border to infect humans, a detailed description of the production of an artificial virus with a pathogenic character marked as that of the 2002-2003 epidemic is given. This virus was a synthetic hybrid, constructed from a human virus responsible for acute respiratory syndrome (SARS) 2002-2003 adapted to the mouse (SARS-MA15).

In the second stage, the mouse-friendly surface protein $S$ (spike) was replaced by spike protein $\mathrm{SHC} 014$ from a bat virus that was identified at the Wuhan Institute. The presence of SHC014 proteins in bat-related coronavirus associated with ACE2 receptors for cell penetration, present in many anchors, is a major discovery of Shi Zheng Li published in Nature in 2013.

The question was whether the SHCO14 protein could activate the human ACE2 receptor directly without adapting to the SARS-CoV S 2002-2003 protein. The produced virus, called SHC014-MA15, was perfectly viable and replicated in airway human cell cultures above concentration levels identical to those observed in patients of the deadly 2002-2003 outbreak /24/.

This protein, SHC014, therefore had the ability to integrate with other viruses to strengthen their pathogenesis to a potentially fatal level comparable to that of the 2003 epidemic!

This has proven that by genetic engineering we can insert, without major problems, into an organism a part of the genetic material of another organism. Thus, the fluorescent jellyfish gene was inserted into a sheep that became fluorescent under UV rays, which was done in
2012. "The question is what have we accomplished and what does it lead to", askes Lounnas?

Before we continue our story of the reign of the Mind in the corona era, we must mention the Dutch scholar Ron Fouchier who played God as well as the aforementioned American Chinese tandem. He genetically modified the deadly avian influenza virus $\mathrm{A} / \mathrm{H} 5 \mathrm{~N} 1$ that has since been capable of spreading among mammals, including man!

"In 2011, Fouchier and Kawaoka alarmed the world by revealing they had separately modified the deadly avian H5N1 influenza virus so that it spread between ferrets. Advocates of such gain of function (GOF) studies say they can help public health experts better understand how viruses might spread and plan for pandemics. But by enabling the bird virus to more easily spread among mammals, the experiments also raised fears that the pathogen could jump to humans. And critics of the work worried that such a souped-up virus could spark a pandemic if it escaped from a lab or was intentionally released by a bioterrorist." /25/

Using a similar argument as that used by Baric and Shi about their experiment, Fouchier justified his Frankenstein venture by saying that he wanted to find a cure for modified bird flu, should this natural modification ever occur and people are threatened!?

For this natural modification to occur, the probability is one to one billion!

Mind, the new Frankenstein and Humane Totalitarianism

The West has once again succeeded in establishing dominance over the rest of the world; the mind, enriched by China, with Russia always being part of the West, can continue to strengthen rational history! Bombings of non-rational societies will be less and less, American torture camps in Europe and Latin America will disappear, threats against the disobedient will no longer be necessary. After COVID-19, such an atmosphere of fear was created that would last for centuries to come. Hegel would say that 
servants who hated their Western masters would now obey them submissively and with divine respect in everything. Suffice it to see how "superfluous" nations, groups and individuals are pleading with the West to provide them with any vaccines against the new coronavirus that, and otherwise, are not needed for $80 \%$ of people, and certainly not now with the emergence of new strains of this virus with unknown characteristics!

Let us review what a French scientific research study of roughly 105, 000 people revealed about the dangers to humans of SARS-CoV-2, without strains:

1. Of young people (from 10-19 years of age) infected with coronavirus, only $21 \%$ of them show symptoms; whereas $69 \%$ of those aged 70 and older are symptomatic.

2. Scientists claim that $80 \%$ of coronavirus-infected do not have any problems, $15 \%$ some problems, and 5\% serious problems: Half of these $5 \%$ with serious problems risk death.

3 . Out of the sample of 105,152 infected patients, the mortality rate was around $20 \%$, the median age for death in France is 84 years! Only $3 \%$ of the dead were under 65 ! Only three deceased persons were under the age of 18 !

4 . The mortality rate from coronavirus is only $2-$ $3 \%$ higher than that of influenza.

5. At 50 years of age and below, there are less than $5 \%$ of an infected person being hospitalized due to pronounced symptoms compared to those who are $70-79$ years of age, $24 \%$ of whom are hospital treated for pronounced symptoms. Of those 40 and under, less than $5 \%$ of those hospitalized needed intensive care versus $27 \%$ of those 60 and $43 \%$ of 70 years and over.

It should be added that for those under 45 who suffer from asthma (which in Great Britain is about 4.3 million) or have some other chronic diseases, $21 \%$ of $25-45$ years may have difficulties if infected with coronavirus.

Of course, the danger to such individuals can be of equal intensity if they have the flu or another infectious disease /26/.

Therefore, it has been established, that $80 \%$ of people will recover from coronavirus without severe health problems. So why do these people need vaccines? Of course, the risk group where mortality is by far the highest is that of over 80 years, but pharmaceutical companies do not guarantee these individuals a harmless and effective vaccine.

Let us add to this the following statement (28.08. 2020.).

"Giorgio Palú, a respected world virologist from the University of Padua, said that there are many who whilst infected are not sick, that is, they have no symptoms. Corona deaths are $300 \%$ Palú says, but on confirmed cases of infection. That is a higher mortality rate than the flu, but we have had a vaccine against it for a very long time, which should be taken into account. In $90 \%$ of cases, corona-infected patients die over 90 years of age."

This kind of data does not correspond to the rational masters of the world - let us imagine, for example, that $80 \%$ of people do not want to be vaccinated. That is because they have 'stimulated' doctors and the media to talk about how, in fact, the new coronavirus is airborne through aerosols, how lethal it is to everyone, and therefore none is exempt, neither the old, the young, male nor female. According to the propaganda being disseminated, the Copernican reversal, the young, instead of the old, have become victims of coronavirus!

Compared to the sudden 'mass death of young people', the media is racing to 'inform' the people about how many new 'coronavirus cases' there are and how many are dying 'by the hour'. It gives the impression that coronavirus is the only cause of death in the world. The campaign is so intense; it has to scare most people who will rush to be vaccinated.

The facts, however, speak differently $/ \mathbf{2 7 /}$. 01/01/2020 to 17 April 2020, 8,576,007 people died worldwide, of which 147,744 people died from the coronavirus, or only $1.67 \%$.

FAMINE: 2,652,272

- CANCER: 2,419,969

- SMOKING: 1,472,982

- ALCOHOL: 736,966

- TRAFFIC ACCIDENTS: 397,754

- SUICIDE: 315,972

-MALARIA: 289,020 
-COVID-19: 147,744

-SEASONAL FLU: 143,323

Therefore, who really knows what people actually die from, and the autopsies of those who supposedly died of coronavirus cannot be done! The symptoms of many respiratory diseases are similar to those of COVID-19.

Here is an incredible media report that proves that methodology determines the cause of death, regardless of its cause:

"The British administration today changed the way it collects data on deaths from the coronavirus, reducing the number of deceased by more than 5,000 !" /28/

In this sense, in some countries, even those killed in car accidents are counted as dying from coronavirus, if, subsequently, postmortem, they are found to have been infected with this virus!

It is most likely, however, that many people died from the flu as attributed to COVID-19! THE EMINENT 'THE ECONOMIST' REVEALED! With the arrival of COVID-19, the flu disappeared, or is it something else? (13.09.2020.)

"The southern hemisphere of the world, where winter is about to end, has mysteriously escaped the flu season this year, but is bathing in many cases of coronavirus, according to the respected British newspaper The Economist.

It supported its assertions with graphs showing the number of infected and influenza deaths between 2015-2019 in countries such as Argentina, Australia, Chile, New Zealand, South Africa, and so on.

All graphs show a huge discrepancy between the number of influenza sufferers in the past years, when there was no COVID-19, and this year. In addition, the number of deaths from influenza per 100,000 inhabitants is much lower this year than in previous years. That is why the number of deaths from COVID-19 is drastically higher.

The question arises from the published data, has the flu completely disappeared, stopped spreading or maybe they died of the flu but this time it was attributed to COVID19 ?"
It is obvious that the intimidation of the population through the media will continue indefinitely and that it is becoming more "imaginative":

"The first cases of patients re-infected after suffering from coronavirus have been reported in Hong Kong and the USA. These findings suggest that people may need to be vaccinated every year, even those who have recovered from the virus infection."

or

"LEAKED SECRET REPORT BY BRITISH GOVERNMENT! They expect coronavirus to become seafaring in the winter months of 2021 ! These figures are unbelievable! Another 80,000 dead!" /29/

or

" Coronavirus immunity has been talked about since the beginning of the pandemic, and scientists have now come up with new, not very good results.

Antibody levels of coronavirus rose and then remained at the same level for up to four months in more than $90 \%$ of patients in Iceland cured of COVID-19, a study published in the 'New England Journal of Medicine' showed." (02. 09. 2020.)

This is to say to tens of millions of people who have gotten over COVID-19, that their immunity is limited to only four months, and that they have to be vaccinated, since the vaccine lasts much longer.

This violence against word and consciousness in order to make a profit has its own other horrific dimension.

The authorities, in some countries and super national communities, realized that they no longer needed old methods of subjugation. Now it is enough for them, for example, from time to time, to release from the lab some new virus or some new, mutated strain of it, so that they make people so frightened, they think of nothing else but saving a naked life.

It will be our future for a long time!

In confirming this:

"The world must better prepare for the next pandemic," said World Health Organization 
(WHO) Director General Tedros Adanom Gebrejesus $(07 / 09 / 2020)$ !

In addition to dictatorial measures, there were other ways of treating the pandemic.

Many countries have introduced draconian protection measures against coronavirus that have turned into a dictatorship over the population. All European governments have already known since 2019 what will happen and have received large amounts of money, not to finance and strengthen the health system and hospitals, but solely to declare quarantine/isolation and ensure its firming through massive police strengthening, Italian journalist Nicola Bizzi reveals. /30/

The reign of the Mind is established again over all states and nations of the world. Those who truly rule are the "rational" elites of the West, including China. They fund the World Health Organization and impose rules of conduct on it in the form of 'recommendations'. National organizations set up crisis headquarters that formally assumed political power and ordered the behavior of local populations. Political structures, media, bureaucracy and social networks have been "stimulated" in various ways to follow the instructions of crisis headquarters. Repressive apparatuses, the military and the police, carry out the orders of the mediocracy. The people, whom they call the herd and to whom many freedoms have been abolished, are, with rare exceptions, convinced that all this is for his own good.

\section{Is SARS-CoV-2 a New, Hybrid, Laboratory Vi-} rus?

We are not going to dwell on that story very long. Like Fouchier, Baric and Shi openly admitted, and published it in eminent scientific journals, that they had made artificial, hybrid, deadly viruses in their laboratories, it meant that it did not matter completely whether the new coronavirus was artificial or not, because it could be produced artificially.

However, since the controversy about this has been going on for more than a year, let us look back at the arguments of those who claimed that this virus was an artificial one.
Indian researchers, most notably Prashant Pradhan, Ashutosh Kumar Pandey, Akhilesh Mishra, Parul Gupta and Bishwajit Kundu have in the 'New Dehia Study' unequivocally proven this.

Simply put, the coronavirus molecule was altered in its four segments by elements of the HIV virus, the one that causes 'AIDS', which completely transformed it, and it took a miracle of God to do so in such a short time and precisely in these places.

Here is a piece of text by Indian scientists where this is exactly what it is claimed:

"We are currently witnessing a major epidemic caused by the 2019 novel coronavirus (2019-nCoV). The evolution of 2019- $n$ CoV remains elusive. We found 4 insertions in the spike glycoprotein (S) which are unique to the 2019-nCoV and are not present in other coronaviruses. Importantly, amino acid residues in all the 4 inserts have an identity or similarity to those in the HIV-1 gp120 or HIV-1 Gag. Interestingly, despite the inserts being discontinuous on the primary amino acid sequence, 3D-modelling of the 2019-nCoV suggests that they converge to constitute the receptor binding site. The finding of $4 u$ nique inserts in the 2019-nCoV, all of which have an identity similarity to amino acid residues in key structural proteins of HIV-1 is unlikely to be fortuitous in nature."

or

"On careful examination of the sequence alignment we found that the 2019-nCoV spike glycoprotein contains 4 insertions. To further investigate if these inserts are present in any other coronavirus, we performed a multiple sequence alignment of the spike glycoprotein amino acid sequences of all available coronaviruses $(n=55)$ in NCBI this includes one sequence of 2019-nCoV. We found that these 4 insertions [inserts 1, 2, 3 and 4] are unique to 2019$n \mathrm{CoV}$ and are not present in other coronaviruses $a$ nalyzed /31/.

Similar to what Indian scientists claimed, and according to a paper published in the journal 'Quarterly Review of Biophysics', the protein 'spike' of the new coronavirus contained some sequences that appear to have been artificially inserted to increase the virus's success. 
In a summary of the paper and later in its elaboration, Norwegian virologist Birger Sorensen and British oncologist Angus Dalgleish claimed to have identified 'inserted parts placed on the surface of SARS-CoV-2 spikes that are crucial for communicating the virus with and entering human cells'.

One of the media reports from that era:

"Two scientists, one British and one Norwegian, recently published a study that could conclude that the SARS-CoV-2 virus was artificially created in a laboratory.

According to a paper published in the journal 'Quarterly Review of Biophysics', the protein spike (spike) of the new coronavirus contains some sequences that appear to have been artificially inserted to increase the success of the virus.

In a summary of the paper and later in its elaboration, Norwegian virologist Birger Sørensen and British oncologist Angus Dalgleish claim to have identified "inserted parts placed on the surface of the SARS-CoV-2 spikes" that are crucial for communicating the virus with and entering human cells.

Sorensen told Norwegian television 'NRK' that the virus has properties that differ greatly from another coronavirus, the causative agent of SARS, and that they were never detected in nature. He argued that China and the United States have been working together for many years to research coronavirus through studies on "acquiring functions" in which the pathogenicity or portability of viruses can be increased to better understand them."

He stated that China and the USA had been collaborating for years on coronavirus studies about "acquiring functions," in which pathogenicity or the virus transmission can be increased to understand it better." /32/

This theory was joined by doctor and Nobel laureate Luc Montagnier.

French virologist, winner of the 2008 Nobel Prize in Physiology and Medicine for isolating the HIV virus, Luc Montagnier, stated that the coronavirus has no natural origin and was made in a laboratory.

"We have come to the conclusion that there has been manipulation of this virus," Montagnier said in an interview with 'CN news' television.
He pointed out that "in SARS-CoV-2, HIV virus particles are also added". /33/

Exiled China scholar Li-Meng Yan and three of her colleagues from the 'Rule of Law Society' and the 'Rule of Law Foundation' in New York, USA, have published two reports on the possible origin of SARS-CoV-2.

In the report, published on September 14 2020, Yan, Shu Kang, Jie Guan and Shanchang $\mathrm{Hu}$ present arguments suggesting that SARS-CoV2 originated in a laboratory in China. Yan, who specializes in virology and immunology at the Hong Kong School of Public Health, fled to the United States in April 2020. Scientists say the SARS-CoV-2 genomic sequence was likely susceptible to genetic engineering manipulation, in which the virus gained the ability to target people with increased contagion. The four scientists argue that the theory that SARS-CoV-2 has a natural origin, although widely accepted, is not supported by evidence. "However, the alternative theory that the virus could come from a research laboratory is strictly censored in scientific journals. SARS-CoV-2 has biological characteristics incompatible with the natural zoonotic virus. /34/

In an article published at the ViXr.org pre-announcement reference site in May, independent researcher Murat Seyran of Vienna states that the host of tropism (specificity of infection of certain pathogens for certain hosts and host tissue) and the SARS-CoV-2 infection sample have three fundamental differences from the previous six human pathogenic coronaviruses. "The SARS-CoV-2 S-Protein S domain sample conflicts with the evolutionary tropism strategy of hosting not only human CVVs, but also many different human pathogenic viruses," Seyran said.

Why haven't we seen the coronavirus pandemic before? asks Seyran. Why didn't pandemics appear where people depend on water sources shared with bats or bats are consumed as bushy meat? Seyran also says that, in the case of SARSCoV-2, the domain of binding S-protein receptors (RBD) is not a high-frequency positive breeding site, unlike other coronaviruses. The SARS-CoV-2 genome is almost identical to the 
bat coronavirus, but is mutated only on RBD, Seyran says. "Why did only RBD have mutations when the rest of the genome is almost unchanged?" It is claimed that the presence of a furine cleavage site in the advanced SARS-CoV-2 protein is proof that the virus did not develop naturally. The location of the furine neckline is a segment of four amino acids that allows the virus to use furine in the human body as an enzyme to dissolve its coating so that it can release its genetic material to infect cells. Furine cleavage spots are usually more addictive than cleavage spots that use other enzymes. Seyran is one of 18 scientists who wrote a letter to the editor of the Journal of Medical Virology, which was published on September $3^{\text {rd }} 2020$. Scientists, from the United States, Austria, Iran, Sudan, India, the United Kingdom, New Zealand, Egypt, Switzerland and Jordan, wrote about the artificial form of the advanced protein SARS-CoV-2. "The SARS-CoV-2 host tropism/adaptation model differs significantly from other $\mathrm{CCVs}$, raising questions about the proximal origin of SARSCoV-2," write Seyran et al. /35/

And so, we could go on indefinitely quoting all those who have expressed doubts ("Conspiracy Theories") about the natural origin of SARS-CoV-2 virus. Of course, a laboratory variant of this virus should not be allowed, as this would automatically mean that SARS-CoV-1 and MERS are also a laboratory product.

\section{Natural origin of the SARS-CoV-2}

The novel SARS-CoV-2 coronavirus that emerged in the city of Wuhan, China, is the product of natural evolution, said Kristian Andersen, $\mathrm{PhD}$, an associate professor of immunology and microbiology at Scripps Research and corresponding author on the paper published in the journal Nature Medicine, march 172020.

Andersen says that this evidence for natural evolution was supported by data on SARSCoV-2's backbone - its overall molecular structure. If someone were seeking to engineer a new coronavirus as a pathogen, they would have constructed it from the backbone of a virus known to cause illness. But the scientists found that the SARS-CoV-2 backbone differed substantially from those of already known coronaviruses and mostly resembled related viruses found in bats and pangolins.

Based on their genomic sequencing analysis, Andersen and his collaborators concluded that the most likely origins for SARS-CoV-2 followed one of two possible scenarios.

In one scenario, the virus evolved to its current pathogenic state through natural selection in a non-human host and then jumped to humans. This is how previous coronavirus outbreaks have emerged, with humans contracting the virus after direct exposure to civets (SARS) and camels (MERS). The researchers proposed bats as the most likely reservoir for SARS-CoV-2 as it is very similar to a bat coronavirus. There are no documented cases of direct bat-human transmission, however, suggesting that an intermediate host was likely involved between bats and humans.

In this scenario, both of the distinctive features of SARS-CoV-2's spike protein - the RBD portion that binds to cells and the cleavage site that opens the virus up-would have evolved to their current state prior to entering humans. In this case, the current epidemic would probably have emerged rapidly as soon as humans were infected, as the virus would have already evolved the features that make it pathogenic and able to spread between people.

In the other proposed scenario, a non-pathogenic version of the virus jumped from an animal host into humans and then evolved to its current pathogenic state within the human population. For instance, some coronaviruses from pangolins, armadillo-like mammals found in Asia and Africa, have an RBD structure very similar to that of SARS-CoV-2. A coronavirus from a pangolin could possibly have been transmitted to a human, either directly or through an intermediary host such as civets or ferrets.

Although the evidence shows that SARS-CoV-2 is not a purposefully manipulated virus, thinks Andersen, it is currently impossible to prove or disprove the other theories of its origin described here. /36/ 


\section{Andersen et al., a critique}

"The question of the origin of the COVID-19 pandemic is, in outline, simple. There are two incontrovertible facts. One, the disease is caused by a human viral pathogen, SARS-CoV-2, first identified in Wuhan in December 2019 and whose RNA genome sequence is known. Second, all of its nearest known relatives come from bats. Beyond any reasonable doubt SARSCoV-2 evolved from an ancestral bat virus. The task the Nature Medicine authors set for themselves was to establish the relative merits of each of the various possible routes (lab vs natural) by which a bat coronavirus might have jumped to humans and in the same process have acquired an unusual furin site and a spike protein having very high affinity for the human ACE2 receptor.

When Andersen et al. outline a natural zoonotic pathway they speculate extensively about how the leap might have occurred. In particular they elaborate on a proposed residence in intermediate animals, likely pangolins...This viral evolution occurred in "Malayan pangolins illegally imported into Guangdong province". Even with these speculations there are major gaps in this theory. For example, why is the virus so well adapted to humans? Why Wuhan, which is $1,000 \mathrm{Km}$ from Guangdong?

The authors provide no such speculations in favour of the lab accident thesis, only speculation against it...

It is also noteworthy that the Andersen authors set a higher hurdle for the lab thesis than the zoonotic thesis...

A further imbalance is that key information needed to judge the merits of a lab origin theory is missing from their account. In their search for SARS-like viruses with zoonotic spillover potential, researchers at the WIV have passaged live bat viruses in monkey and human cells. They have also performed many recombinant experiments with diverse bat coronaviruses. Such experiments have generated international concern over the possible creation of potential pandemic viruses...The Shi lab had also won a grant to extend that work to whole live animals. They planned "virus infection experiments a- cross a range of cell cultures from different species and humanized mice" with recombinant bat coronaviruses. Yet Andersen et al did not discuss this research at all...

A further important oversight by the Andersen authors concerns the history of lab outbreaks of viral pathogens. They write: "there are documented instances of laboratory escapes of SARS-CoV". This is a rather matter-of-fact allusion to the fact that since 2003 there have been six documented outbreaks of SARS from labs, not all in China, with some leading to fatalities.

Andersen et al might have also have noted that two major human pandemics are widely accepted to have been caused by lab outbreaks of viral pathogens, H1N1 in 1977 and Venezuelan Equine Encephalitis. Andersen could even have noted that literally hundreds of lab accidents with viruses have resulted in near-misses or very localised outbreaks.

Also unmentioned were instances where a lab outbreak of an experimental or engineered virus has been plausibly theorised but remains uninvestigated. For example, the most coherent explanation for the H1N1 variant 'swine flu' pandemic of 2009/10 that resulted in a death toll estimated by some as high as 200,000 , is that a vaccine was improperly inactivated by its maker. If so, H1N1 emerged from a lab not once but twice.

Given that human and livestock viral outbreaks have frequently come from laboratories and that many scientists have warned of probable lab escapes... the Andersen paper is not an even-handed treatment of the possible origins of the COVID-19 virus. Yet its text expresses some strong opinions: "Our analyses clearly show that SARS-CoV-2 is not a laboratory construct or a purposefully manipulated virus....It is improbable that SARS-CoV-2 emerged through laboratory manipulation of a related SARS-CoVlike coronavirus.....the genetic data irrefutably show that SARS-CoV-2 is not derived from any previously used backbone....the evidence shows that SARS-CoV2 is not a purposefully manipulated virus....we do not believe that any type of laboratory-based scenario is possible." (Andersen et al., 2020)... 
Since the publication of Andersen et al., important new evidence has emerged that undermines their zoonotic origin theory. On May 26th the Chinese CDC ruled out the Huanan "wet" market in Wuhan as the source of the outbreak. Additionally, new research on pangolins, the favoured intermediate mammal host, suggests they are not a natural reservoir of coronaviruses. Furthermore, SARS-CoV-2 was found not to replicate in bat kidney or lung cells (Rhinolophus sinicus), implying that SARS-CoV-2 is not a recently-adapted spill over." /37/

Most importantly, however, is what the World Health Organization will say. Its representatives recently returned from China after trying to find out how the COVID-19 pandemic occurred. Here is the statement of the WHO commission.

Peter Ben Embarek, a member of the WHO team located in Wuhan, said they found no evidence that in December 2019 the virus circulated widely outside the fish market from where the spread of the infection allegedly began.

He added that the WHO team has come up with new information, but that they do not alter the overall picture of the outbreak of the pandemic.

"The hypothesis that the coronavirus escaped from the laboratory is extremely incredible and we will take this into account in further studies of the origin of the virus," Ben Embarek stated.

\section{CONCLUSION}

There are some facts about beta corona viruses ( $\beta$-CoVs) to be highlighted:

- In 2019, a novel CoV (SARS-CoV-2) causing respiratory illness (COVID-19) was reported in Wuhan, Hubei province, China. This emerging human virus is closely related to SARS-CoV (1), and appears to have originated in horseshoe bats - with its full genome $96 \%$ similar to a viral sequence reported from Rhinolophus affinis. Closely related sequences were also identified in Malayan pangolins.

- Despite the high degree of similarity in parts related to bat RaTG13 and RBD to pangolin SARS-CoV, the immediate predecessor to human SARS-CoV-2 remains unclear, elusive.
- What is characteristic of the three, quite different, deadly beta coronaviruses (SARS-CoV1, MERS, SARS-CoV-2) which appear every eight years (from 2002 to 2019), is the fact that in no case could be found a way to pass the virus from bat to an intermediary host (spillover), from bats to camels (MERS), and from bats to civets and pangolins (SARS 1,2).

-It is impossible that in the three above-mentioned cases, spillovers occurred evolutionary, naturally in a historically very short period of 18 years.

- Since artificial (synthetic, hybrid) viruses (SHC014-MA15, modified H5N1) have already been created, it is possible that the three mentioned viruses (SARS 1.2 and MERS) are a laboratory product.

- In that case, either they escaped the laboratories carelessly, or were deliberately designed in order to make for their creators, by spreading the pandemic, significant political, economic and other advantages.

Humankind will never be as it was before the COVID-19 pandemic. It was imposed by the world right wing whose ideology based on Hegel's totalitarian vision of the world, on absolute rationality, shaped in the form of a "cunning Mind". That right wing constantly, hypocritically, emphasizes its concern for the well-being of humanity. It has the knowledge, means and power to produce, at will, hybrid viruses and their human-dangerous strains, constantly claiming that these are natural viruses created by evolution. To defend his truth, the "cunning Mind" has its instruments: health organizations, mainstream media, political structures and repressive state organs that sanction every free thought. Similar social complexes existed in the middle Ages, as in the twentieth century in the form of totalitarian systems.

When we say that nothing will be like before COVID-19, we mean primarily the fear and anxiety that has engulfed the world's population. This fear will continue to be sustained by all manipulative means, primarily with the help of science which, thanks to the "cunning Mind' has become utterly inhuman. People will feel so miserable, that they will not care about democracy or freedom anymore. To caricature Sartre, 
the existence will suppress the essence. Soon, in the name of absolute rationality, for "practical reasons", population chipping will be done and totalitarian control over people will be irreversible.

\section{Notes}

/1/ For fairness, we will speak of the historical course of Western civilization that claims to be universal torchbearer and the main subject of development of humankind, something that other civilizations negate. However, according to the author of this article, steady progress of rationality, the concept and practice of the West, is indeed the fate of humanity. This applies particularly to scientific determinism in the natural sciences, without which humankind would soon become extinct.

/2/ The LORD God made garments of skin for Adam and his wife and clothed them. And the LORD God said, "The man has now become like one of us, knowing good and evil. He must not be allowed to reach out his hand and take also from the tree of life and eat, and live forever."

/3/ Let us recap. The European, Judeo-Christian civilization, along numerous wanderings, conceptually accepted the formal logic (the ultimate, absolute rationality) as the "nec plus ultra" (Latin "nothing further beyond") of its existence. It has been so from Biblical times to the present day: Judaism, Ancient Greece, Rome, Christianity (St Thomas Aquinas, scholasticism), enlightenment, Hegel, positivism. This kind of rationality could have been developed by other peoples and civilizations, possibly even better and more fully then in the West. However, upon specific and not racist reasons, the Islamic world and China, were far less developed, inconsistent and / or underutilized. Despite the fact that sometimes in their discoveries they stood above Europe. Thus the West gained a huge advantage by developing powerful weapons, ships, rational administration, relations of dominance and everything else necessary for colonization, exploitation and destruction.

/4/ Much is said of how SET Revolution (Industry pollution - the destruction of nature - the ozone hole, nuclear power - A bomb, biotechnology transgenic crops - growth hormone) are threatening to destroy all of humanity. Problems are clearly serious. But all progress brings with it new uncertainties and dangers. It is true that a civilization based on profit is disregards preservation of nature. However, with the progress of rationa- lity, it is inevitable that nature becomes more adapted for humans and less primeval. All this is calculated in by progress and it is clear that these new problems that threaten human existence, must be urgently addressed.

/5/ By Kristi Or, July 6 2020, TATLER

/6/Like Alice through the Looking Glass... She used to know who she was Call out my name But I get no answer And she prays for the world that she comes from. (Stevie Nicks, The other side of the mirror)

/7/“Is our national empathy-our care and love and concern for one another-at such a low level that we are not truly feeling, in our bones, in our hearts, and in our souls, the magnitude of the loss?" 'THE ATLANTIC', OLGA KHAZAN SEPTEMBER 22, 2020

/8 /BY NOAH BERLATSKY, JANUARY 19, 2021, 3:05 PM, FP

/9/By Emma Grey Ellis, 05.02.2020 07:00 AM

/10/ By Zoe Schiffer and Nicole Wetsman Aug 28, 2020, 8:00am EDT, The VERGE

$/ 11 /$, One recent study of a Chicago-area nursing home found that from December 2019 to the end of April 2020, two-thirds of the residents had lost weight, in some cases dramatically - a change that researchers attributed to reduced social interaction, the cessation of family visits and schedule changes due to the pandemic. Confinement, social isolation and the lack of external stimulation are also fueling cognitive decline and depression, which in turn increase the risk of high blood pressure, heart disease and stroke, according to Dr. Louise Aronson, a geriatrician and professor of medicine at the University of California, San Francisco. Sometimes the doors to their rooms are open, and you just see someone sitting in a chair with tears running down their face. Aronson, who is assisting San Francisco's response to the pandemic in longterm care facilities, said. 'People ask me, is this the rest of my life? If so, I don't want to go on'." 'NEWS' Oct. 27, 2020, 4:45, By Suzy Khimm

/12/ BBC NEWS, 21/04/2020

/13/ https://www.forbes.com > forbes-400

114/ BBC News, Extreme poverty set for first rise since 1998, World Bank warns Published 7 October 2020

/15/ The rate of false negatives - a test that says you don't have the virus when you actually do have the virus - varies depending on how long infection has been present: in one study, the falsenegative rate was $20 \%$ when testing was performed five days after symptoms began, but much higher (up to $100 \%$ ) earlier in infection. The false positive rate - that is, how often the test says you have the virus when you actually do not - 
should be close to zero. Most false-positive results are thought to be due to lab contamination or other problems with how the lab has performed the test, not limitations of the test itself. AUGUST 10, 2020, 10:30 AM , Robert H. Shmerling, MD, Harvard Medical School

/16/ According to 2018 US Census Data, the highest poverty rate by race is found among Native Americans $(25.4 \%)$, with Blacks $(20.8 \%)$ having the second highest poverty rate, and Hispanics (of any race) having the third highest poverty rate $(17.6 \%)$. Whites had a poverty rate of $10.1 \%$, while Asians had a poverty rate at $10.1 \%$.

/17/Frontiers in sociology, W. Holmes Finch and Maria E. Hernández Finch, 15 June 2020 I https://doi.org/10.3389/fsoc.2020.00047

/18/ "The cunning Mind" is concerned that the development of science and technology (SET) increases the chance of survival of man and mankind. Thus, it cares little about the suffering that the path of development of self-awareness generate. This view seems to be that the self-developing Mind, in some of its stages, does not recognize common moral principles. Things are, historically speaking extremely frustrating in that regard. One can, factually speaking, claim that the "cunning Mind", in every epoch, sacrifices masses in the favor of progress of rationality. European civilization, including the recent American, for thousands of years dominated, exploited and destroyed other, according to western standards, less rational, "lower class civilizations." Who cares in this time for, example, that white settlers in the current US destroyed millions of Indians to build the modern America? Who cares that West, for hundreds of years and by extremely cruel manner, exploited slave labor and turned the non-European world into colonies that were plundered for centuries? Who cares that white settlers in Australia destroyed Aboriginals in order to create a prosperous country?

/19/ Bats are speculated to be reservoirs of several emerging viruses including coronaviruses (CoVs) that cause serious disease in humans and agricultural animals. These include $\mathrm{CoVs}$ that cause severe acute respiratory syndrome (SARS), Middle East respiratory syndrome (MERS), porcine epidemic diarrhea (PED) and severe acute diarrhea syndrome (SADS). Bats that are naturally infected or experimentally infected do not demonstrate clinical signs of disease.

/20/ Live MERS-CoV has been successfully isolated and cultured from camel specimens. Approximately $55 \%$ of primary MERS-CoV cases are a result of direct contact with dromedary camels or camel products; however, the remainder of primary MERS-
CoV cases have no history of contact with camels or infected individuals and thus, where they came into contact with the virus is unknown.

/21/ Civets have been considered one of the most likely animals responsible for animal-to-human SARS-CoV transmission, and on this basis, more than a thousand civets in Guangdong were culled in January 2004. However, no conclusive evidence suggests that civets are the natural reservoir host of SARS-CoV or that civets in their natural habitat are infected with SARS-CoV.

/22/ The ongoing outbreak of viral pneumonia COVID 19 is associated with a new coronavirus, SARS-CoV-2. This outbreak has been tentatively associated with a seafood market in Wuhan, China, where the sale of wild animals, especially pangolins, may be the source of zoonotic infection. Although bats are probable reservoir hosts for SARS-CoV-2, the identity of any intermediate host that may have facilitated transfer to humans is unknown.

/23/ Valère Lounnas, Histoire de la Covid, chapitres: 2, 2 et 3, 2, France-Soir, 08/06 et 07/09/2020

/24/ MAIN (part of the Baric - Shi) article

“...To test the ability of the SHC014 spike to mediate infection of the human airway, we examined the sensitivity of the human epithelial airway cell line Calu-3 2B4 (ref. 9) to infection and found robust SHC014-MA15 replication, comparable to that of SARS-CoV Urbani (Fig. 1c). To extend these findings, primary human airway epithelial (HAE) cultures were infected and showed robust replication of both viruses (Fig. 1d). Together, the data confirm the ability of viruses with the SHC014 spike to infect human airway cells and underscore the potential threat of cross-species transmission of SHC014-CoV." (It cannot be more clear, E. V.) A SARS-like cluster of circulating bat coronaviruses shows potential for human emergence Vineet D Menachery, Boyd L Yount Jr, Kari Debbink, Sudhakar Agnihothram, Lisa E Gralinski, Jessica A Plante, Rachel L Graham, Trevor Scobey, Xing-Yi Ge, Eric F Donaldson, Scott H Randell, Antonio Lanzavecchia, Wayne A Marasco, Zhengli-Li Shi \& Ralph S Baric Published: 09 November 2015 Nature Medicine, volume 21, pages1508-1513(2015) 30 March 2020 Editors' note, March 2020: We are aware that this article is being used as the basis for unverified theories that the novel coronavirus causing COVID-19 was engineered. There is no evidence that this is true; scientists believe that an animal is the most likely source of the coronavirus. 
/25/ Jocelyn Kaiser, Controversial experiments that could make bird flu more risky poised to resume, Feb. 8, 2019.

/26/ 'LesEchos', 16 juin, 2020; Sante publique France, Covid 19, Point épidémiologique hebdomadaire du 9 juillet 2020

/27/ BN TV, BiH, 17/04/2020, source: world meters

/28/ TV N1 BiH, 12. 2020. 22:14

/29/ By Deborah Cohen, BBC Newsnight, Published 29 August 2020

130/ ESCLUSIVO, Il Giornalista Nicola Bizzi: “Sapevano Del Coronavirus Dallo Scorso Autunno"

By Davide Donateo Last updated Set 7, 2020

Which world institution has gave money, and how much money exactly?

I am a historian, a writer and a freelance journalist. It is since last January, with the introduction in Italy of the state of emergency by the government of Giuseppe Conte, that I feel myself at war, literally catapulted night and day into a trench. I feel at war certainly not against a "virus" or an invisible enemy, but against a government that is totally heterodirected by very dangerous forces and powers that have staged a real global coup aimed at the progressive reduction and cancellation of democracy, freedom and civil rights, the repression of any dissent and the establishment of a world-wide Orwellian technocratichealth dictatorship. This plan, which has been going on undisturbed for many years and which unfortunately also sets itself other even more dangerous objectives, has directly involved most of the world's governments and some Europeans in particular.

Not all European countries approached the Corona Operation in the same way, although, at least in the initial phase, all supported it, also because they know that it is functional to an economic reset from which they would not want to be excluded. However, in the Scandinavian countries, Switzerland, Croatia and, in part, Germany, the operation soon clashed with the solidity of democratic systems and a partial backtracking took place, a real attempt to unmark. In other countries, such as Italy, Spain, France, Serbia and Bulgaria, the operation was carried out with greater force and violence. This was due to increased international pressure and, certainly, to greater economic incentives coming from organizations such as WHO and IMF. All European governments already knew from September 2019 what would happen and have received enormous clandestine funding (not officially declared), a real rain of money, certainly not to finance and strengthen health care and hospitals, but exclusi- vely to declare the lockdown and to ensure its sealing through the massive strengthening of the Police.

I do not know the exact amounts of these loans, also because they have been covered by state secret and because they have been different from country to country. But to break the barrier of silence was the President of Belarus Aljaksandr Lukashenko, who has notoriously always refused to adopt any emergency, lockdown or "social distancing" measures in his country. At a meeting of the Belarusian government, he declared that he had received a large cash offer (92 million dollars) from the World Health Organization, to do "like in Italy". An offer that, after Lukashenko's refusal, would have even increased tenfold in a few weeks: 940 million dollars, this time offered by the International Monetary Fund, accompanied by the same request: close everything and do "as in Italy". Not surprisingly, after this courageous stance, Lukashenko has been demonized by the "international community", has been accused of electoral fraud and is trying to overthrow him with a ridiculous and petty "color" revolution financed by criminals like George Soros and fueled by servants of globalist power like Bernard Henry Levy.

131/ Uncanny similarity of unique inserts in the 2019$n$ CoV spike protein to HIV-1 gp120 and Gag https://doi.org/10.1101/2020.01.30.927871 Prashant Pradhan, Ashutosh Kumar Pandey, Akhilesh Mishra, Parul Gupta, Praveen Kumar Tripathi, Manoj Balakrishnan Menon, James Gomes, Perumal Vivekanandan, and Bishwajit Kundu Kusuma School of biological sciences, Indian institute of technology, New Delhi-110016, India. Acharya Narendra Dev College, University of Delhi, New Delhi-110019, India

(E. V., Two days after publishing, this report was withdrawn!?)

/32/ Scientists claim to have proof COVID-19 is artificially created. Are they right? Nenad Jarić Dauenhauer 15.6.2020.

/33/ French Nobel prize winner: 'Covid-19 made in lab' 'The Connexion', French news and views A controversial French Nobel prize-winning scientist has accused biologists of having created SARS-CoV-2 - the virus that causes Covid-19 - in a lab, but the wider scientific community has so far refuted the claim. 22 April 2020

By Connexion journalist

Luc Montagnier, who won the Nobel Prize in 2008 for his work on HIV - and who is a very controversial 
figure in the scientific community - said in an interview this week that "the virus has come out of a laboratory in Wuhan, which has been specialising in these types of coronaviruses since the beginning of the 2000s".

He made the claim during an interview with news platform CNews.

He said: "We have arrived at the conclusion that this virus was created." He accused "molecular biologists" of having inserted DNA sequences from HIV into a coronavirus, "probably" as part of their work to find a vaccine against AIDS.

He said that it was not clear how the virus had been able to escape the laboratory, and condemned scientists for doing "the work of a sorcerer's apprentice".

Professor Montagnier has said that he is not the first to suggest the connection, and added that "a group of renowned Indian researchers" had also tried to publish a study showing that the new coronavirus includes HIV DNA, but were forced to retract their claims and had been "smothered".

The Indian study said that there was "a strange similarity" between the new coronavirus SARS-CoV-2 and VIH-1 - the main cause of HIV - "which is unlikely to be coincidental".

But an article in Le Monde newspaper found that this alleged Indian study had been "pre-published", before it had been read by academic peers [a necessary step for any academic paper before it is published in a recognised journal].

After its "pre-publication", the article was widely criticised by the scientific community, with many saying that such similarities were "banal", and very common among similar viruses.

Following intense criticism, the study was later taken down.

The site that pre-published the study, BioRxiv, said that its publications were not peer-reviewed, and that "they should not be considered as conclusions, health advice, clinical guidelines, or to be used by the press as definite information".

The similarity between Covid-19 and HIV has also been noted by Peng Zhiyong, director of intensive care at the Zhongnan university hospital in Wuhan. In an interview with official Chinese media site Global Times, he said: "The influence of Covid-19 on the body is like a combination of SARS and AIDS."
The doctor was referring to symptoms of the virus including its effect on the lungs and immune system - and did not explicitly say that the viruses themselves were in any way similar.

Claims 'make no sense'

Professor Montagnier's claims that the virus was created in a laboratory do not align with the current consensus of the wider scientific community.

The World Health Organization (WHO) has denied any suggestions that the virus was "made in a laboratory".

Currently, it is widely thought that the new coronavirus appeared from a wet market in Wuhan, in China, where many exotic animals are sold.

Conspiracy theories?

Yet, there is no shortage of conspiracy theories circulating about the claim.

A study by polling agency Ifop - published at the end of March - found that more than $26 \%$ of French people believe that the new coronavirus "was intentionally made in a laboratory"; a figure that jumps to $40 \%$ among voters of far-right party le Rassemblement National.

A number of right-wing and extreme-far-right figures in France have made reference to Professor Montagnier's claims - notably on Twitter - with some linking the theory to what they see as a "lack of transparency" from China about the virus.

134/ Chinese defector virologist Dr Li-Meng Yan publishes report claiming COVID-19 was made in a lab, 'The Australian'. Wednesday, March 3, 2021

/35/ 'Changing Times', Covid-19: as vaccine race gains pace, the origins and evolution of SARS-CoV-2 intrigue scientists BY ANNETTE GARTLAND ON JULY 10, 2020

136/ Nature Medicine, 26, The proximal origin of SARSCoV-2 Kristian G. Andersen, Andrew Rambaut, W. Ian Lipkin, Edward C. Holmes \& Robert F. Garry

137/ Independent Science News, Jonathan Latham, PhD and Allison Wilson, PhD, A Proposed Origin for SARS-CoV-2 and the COVID-19 Pandemic 


\title{
KORONA VIRUS U SVJETLU FILOZOFIJE
}

\author{
Emil Vlajki \\ Fakultet političkih znanosti, Sveučilište u Banjoj Luci, Banja Luka, Bosna i Hercegovina
}

Sažetak

Povijest čovječanstva je, prvenstveno, povijest racionalnosti. Zahvaljujući njoj, čovjek je iz kamenog doba dospio u doba suvremene medicine, genetike, informatike, robotike, nanotehnologije, i da ne nabrajam. Životni vijek Krapinskog čovjeka bio je oko dvadeset godina, a danas, $\mathrm{u}$ visoko razvijenim društvima čovjek živi, u prosjeku, osamdeset šest godina. Napredak znanosti i tehnologije nije uvijek pozitivan. Dovoljno je spomenuti ekološke probleme koji ozbiljno prijete čovječanstvu ili, na primjer, probleme u prehrani vezanoj za genetske manipulacije. Pokazuje se da se znanstveno-tehnološki razvitak mora ozbiljno, filozofski promišljati. Etika postaje sve više sastavni dio života. U ovom smo se radu fokusirali na probleme vezane za novi Coronavirus koji je prouzrokovao bolest planetarnih razmjera nazvanoj Covid 19. Ne može se osporiti činjenica da su se sve zemlje angažirale da suzbiju nastalu pandemiju. Međutim, upotrijebljene mjere izazivaju izvjesna podozrenja. Da li treba zatvarati ljude u karantenu, da li im treba ograničavati kretanje, da li ih treba prisiljavati na cijepljenje, i slično. Tvrdeći da djeluju profilaktički, znanstvenici su dodavanjem nekih DNK, RNK segmenata (gain of fonction, GOF) neškodljivom virusu za čovjeka, stvorili opasan umjetni virus gripe. Isto tako je, laboratorijski, stvoren umjetan, infektivan Coronavirus. Oba postupka stvaranja ovih opasnih, hibridnih virusa su opisani u eminentnim znanstvenim časopisima! Znanstvenici su nam rekli da su to uradili kako bi pronašli lijekove i vakcine protiv ovih ne-prirodnih virusa ukoliko se oni ikada pojave među ljudima; opreznim rukovanjem, medicinska znanost se može unaprijediti. Ali šansa da se ta vrsta virusa pojavi među ljudima je skoro nepostojeća. Što, međutim, ako ti virusi „pobjegnu“ iz laboratorije, kao što se to u nedavnoj prošlosti dešavalo? Što ako ih upotrijebi neka teroristička organizacija ili, po detaljno objavljenim uputama, sama počne proizvoditi te i druge viruse? Konačno, što se tiče dviju velikih svjetskih sila, SAD i Kine, koje su zajednički stvorile umjetan Coronavirus, nazvan SHC014-MA15, tko ih može spriječiti da i dalje nastave s tom praksom? Zar nije moguće da su također stvorile i sadašnji SARS-CoV-2 koji je do sada uzrokovao smrt dva i pol milijuna ljudi? U vezi ovih pitanja, posljednji problem kojim se ova studija bavi, tiče se tolerancije. Veliki broj svjetski renomiranih znanstvenika smatra da je sadašnji uzročnik pandemije, SARS-CoV-2, umjetan, laboratorijski stvoren virus, iznoseći za to niz činjenica. Nije sporno da su njihove tvrdnje sporne. To, međutim, ne znači da ih njihovi protivnici, farmaceutske kompanije i neke svjetske velesile, koji imaju daleko veću političku i ekonomsku moć, moraju posvuda, krajnje nekorektno, blamirati, zabranjivati njihove tekstove na tu temu i moralno ih diskreditirati. U znanosti se borba mora voditi argumentima, a ne totalitarnim orvelovskim metodama.

\section{Ključne riječi}

Hegel, filozofija povijesti, racionalnost, „lukavi Um“, geopolitika, etika, komunikacija, genetika, Coronavirus, znanstveno-tehnološki razvoj, budućnost čovječanstva 